\title{
Penyisihan Konsentrasi Logam Zn Menggunakan Mangrove Avicennia marina
}

\author{
Isbir Farhan dan Mohammad Razif \\ Departemen Teknik Lingkungan, Fakultas Teknik Sipil dan Perencanaan, Institut Teknologi Sepuluh Nopember \\ (ITS) \\ e-mail: razif@its.ac.id
}

\begin{abstract}
Abstrak-Hutan mangrove di Indonesia terutama Pulau Jawa terus mengalami degradasi akibat konversi peruntukan yaitu tambak, penebangan kayu mangrove untuk berbagai keperluan, disamping rendahnya kesadaran masyarakat tentang fungsi ekologis hutan mangrove dan ketidakpastian status kawasan. Keseimbangan ekologi lingkungan perairan pantai akan tetap terjaga apabila keberadaan mangrove dipertahankan karena mangrove dapat berfungsi sebagai biofilter, agen pengikat dan perangkap polusi, penangkap sumber pencemar yang sangat banyak dan memiliki toleransi yang tinggi terhadap logam berat. Tujuan dari penelitian ini adalah untuk menghitung seberapa besar efisiensi mangrove Avicennia marina dalam meremoval larutan artifisial logam $\mathrm{ZnSO}_{4}$. Pada penelitian ini digunakan variabel konsentrasi polutan larutan artifisial $\mathrm{ZnSO}_{4}$ setelah dilakukan uji pendahuluan Range Finding Test. Variabel konsentrasi setelah uji Range Finding Test yaitu 100 $\mathrm{mg} / \mathrm{L}, 200 \mathrm{mg} / \mathrm{L}$ dan $300 \mathrm{mg} / \mathrm{L}$ dengan pengulangan tiga kali/triplo. Pada penelitian ini digunakan reaktor skala laboratorium dengan sistem batch. Berdasarkan hasil penelitian, efisiensi removal mangrove Avicennia marina pada konsentrasi $100 \mathrm{mg} / \mathrm{L}$ yaitu $79,83 \%$, pada konsentrasi 200 mg/L yaitu 70,75\% dan konsentrasi 300 mg/L yaitu $67,17 \%$.
\end{abstract}

Kata Kunci-Mangrove, Logam Zn, Avicennia marina, Spektrofotometer.

\section{PENDAHULUAN}

$\mathrm{H}$ UTAN mangrove di Indonesia terutama Pulau Jawa terus mengalami degradasi akibat konversi peruntukan yaitu tambak, penebangan kayu mangrove untuk berbagai keperluan,disamping rendahnya kesadaran masyarakat tentang fungsi ekologis hutan mangrove dan ketidakpastian status kawasan [1]. Kondisi tersebut sebagai akibat dari adanya pertambahan penduduk yang sangat pesat, yang membutuhkan lahan untuk pemukiman dan kebutuhan hidup sehari-hari. Dengan demikian hutan mangrove sebagai ekosistem pesisir yang pada akhirnya berdekatan dengan pusat-pusat pemukiman penduduk akan menjadi sangat rawan ancaman dan tekanan, sehingga kelestariannya sangat rentan terhadap perubahan lingkungan [2]. Berbagai hasil sisa kegiatan manusia di daratan, seperti limbah domestik, pertanian dan perindustrian berujung di daerah muara sungai dan pantai. Kelompok masyarakat dan industri memiliki anggapan bahwa sungai dan laut merupakan keranjang sampah yang dapat digunakan untuk membuang sampah dengan cara yang sangat mudah dan murah. Pengelolaan lingkungan masih dipandang sebagai beban bagi pengusaha dan pengambil keputusan tidak begitu mudah terdorong untuk mengadopsi aspek lingkungan dalam kebijakannya.
Fungsi dan manfaat mangrove telah banyak diketahui baik sebagai tempat pemijahan ikan di perairan, pelindung daratan dan abrasi oleh ombak, pelindung dari tiupan angin, penyaring intrusi air laut ke daratan, habitat satwa liar, tempat singgah migrasi burung dan menyerap kandungan logam berat yang berbahaya bagi kehidupan, mengendapkan lumpur dan menyaring bahan pencemar. Keseimbangan ekologi lingkungan perairan pantai akan tetap terjaga apabila keberadaan mangrove dipertahankan karena mangrove dapat berfungsi sebagai biofilter, agen pengikat dan perangkap polusi, masukkan sumber pencemar yang sangat banyak dan memiliki toleransi yang tinggi terhadap logam berat [3]. Penyerapan logam berat oleh akar pohon dipengaruhi sistem perakaran dan luasan permukaan akarnya, sebagai contoh: Rhizopora Micronata dapat menyerap Cadmium (Cd) sebesar 17,933 ppm, Rhizopora apiculata memiliki kemampuan menyerap Cd sebesar 17,433 ppm sedangkan Avicenna marina hanya mampu menyerap Cd sebesar 0,5 ppm [4].

Bahan pencemar dari limbah industri dapat mencemarkan air sungai dan berdampak negatif yaitu terjadinya perubahan ekosistem muara berupa perubahan temperatur, $\mathrm{pH}$, BOD dan COD serta kandungan logam berat yang sangat mempengaruhi kehidupan flora dan fauna perairan. Salah satu industri yang limbahnya mengandung logam berat adalah industri elektroplating. Elektroplating atau lapis listrik (penyepuhan) merupakan salah satu proses pelapisan bahan padat dengan lapisan logam menggunakan arus listrik melalui suatu larutan elektrolit [5]. Kandungan logam berat yang terdapat pada limbah industri elektroplating adalah ion kromium valensi VI $\left(\mathrm{Cr}^{6+}\right)$, kromium total $\left(\mathrm{Cr}_{\text {tot }}\right)$, Sianida $\left(\mathrm{CN}^{-}\right)$, Tembaga $\left(\mathrm{Cu}^{2+}\right)$, Seng $\left(\mathrm{Zn}^{2+}\right)$, Nikel $\left(\mathrm{Ni}^{2+}\right)$, Timbal $\left(\mathrm{Pb}^{2+}\right)$, dan $\operatorname{Kadmium}\left(\mathrm{Cd}^{2+}\right)$ [6]. Konsentrasi dari beberapa logam seperti $\mathrm{Cr}, \mathrm{Ni}, \mathrm{Zn}$ lebih tinggi daripada kadar yang dipernolehkan untuk dibuang. Menurut Peraturan Gubernur Jawa Timur Nomor 52 Tahun 2014 mengenai baku mutu air limbah industri pelapisan logam, kadar maksimum logam $\mathrm{Cr}$ total yaitu $0,5 \mathrm{mg} / \mathrm{L}, \mathrm{Cr}^{6+}$ 0,1 mg/L, Cu 0,6 mg/L, Zn $1 \mathrm{mg} / \mathrm{L}, \mathrm{Ni} 1 \mathrm{mg} / \mathrm{L}, \mathrm{Cd}$ 0,05 mg/L dan $\mathrm{Pb} 0,1 \mathrm{mg} / \mathrm{L}$. Oleh karena itu, diperlukan pengolahan yang sesuai untuk menyisihkan logam berat ini dari air limbah sebelum dilepaskan ke dalam lingkungan [7]. Jenis mangrove Avicennia marina digunakan karena sudah terdapat beberapa penelitian terdahulu bahwasanya jenis mangrove ini dapat meremoval logam berat dan juga merupakan jenis yang mayor pada ekosistem hutan mangrove. Logam $\mathrm{Zn}$ diukur karena merupakan logam yang berbahaya. Keberadaan logam Zn pada air yang hanya $1 \mathrm{mg} / \mathrm{L}$ dapat menyebabkan penyakit hemochromatosis dan gastrointestinal dalam hati dan ginjal [8]. 


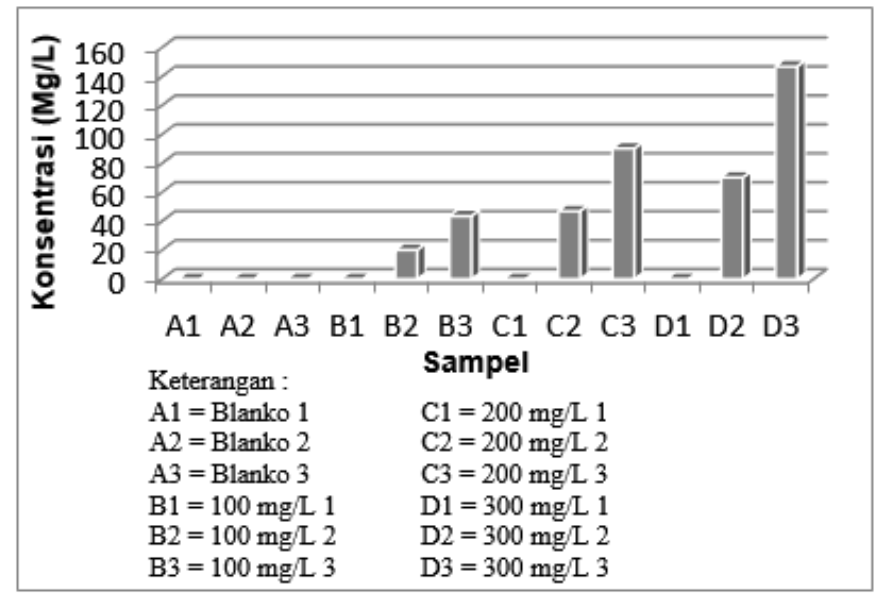

Gambar 1. Removal limbah artifisial logam Zn hari ke -5.

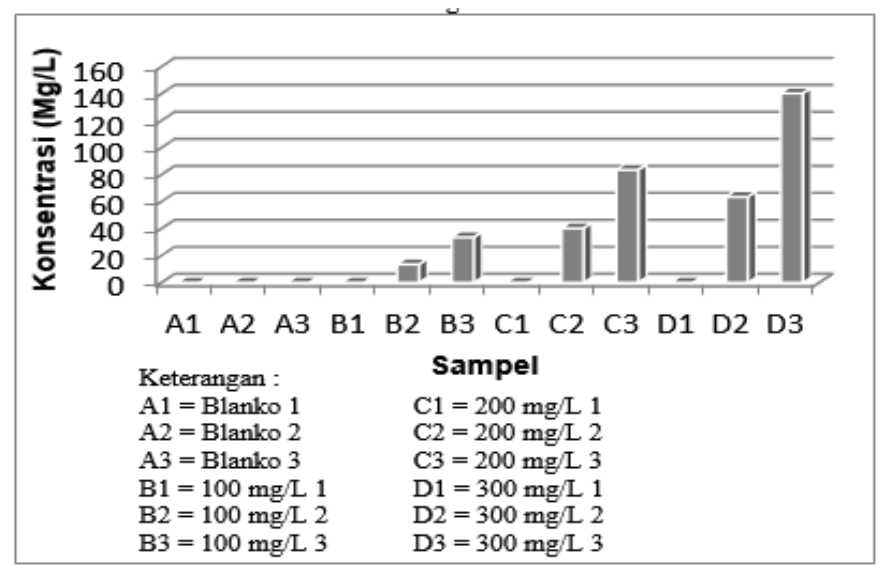

Gambar 2. Removal limbah artifisial logam Zn hari ke - 10 .

Logam Zn menjadi perhatian karena toksisitas dan non biodegredabilitas dengan dampak negatif pada ikan ketika dilepaskan ke sungai [9]. Oleh karena itu perlu dilakukan penelitan untuk mengetahui peranan mangrove Avicennia marina terhadap paparan logam Zn.

\section{II.METODE PENELITIAN}

Penelitian ini membahas tentang peranan Avicennia marina dalam menyerap logam berat $\mathrm{Zn}$ dengan sistem batch. Sampel yang digunakan adalah sampel larutan artifisal $\mathrm{Zn}$ dalam bentuk $\mathrm{ZnSO}_{4}$ dengan berbagai variasi konsentrasi. Sampel larutan artifisial adalah sampel buatan yaitu dengan membuat larutan $\mathrm{ZnSO}_{4}$. Variabel yang digunakan adalah jenis mangrove Avicennia marina dengan variasi konsentrasi larutan sampel artifisial $\mathrm{ZnSO}_{4}$ dengan berbagai konsentrasi yang sebelumnya dilaksanakan uji Range Finding Test terlebih dahulu. Parameter utama yang diukur yaitu logam berat $\mathrm{Zn}$ sedangkan parameter kontrollingnya yaitu suhu dan $\mathrm{pH}$. Penelitian ini merupakan penelitian eksperimental skala laboratorium dengan menggunakan Spektrofotometri UV-VIS.

Umur tanaman yang digunakan yaitu 90 hari.Lama pengamatan yaitu selama 20 hari untuk mengetahui kemampuan optimum tanaman mangrove dalam menyerap logam dimana sampel diambil selama 5 hari sekali. Penelitian dilakukan dengan ulangan tiga kali/triplo dimana di setiap media tanam terdapat 1 tanaman mangrove. Sehingga untuk

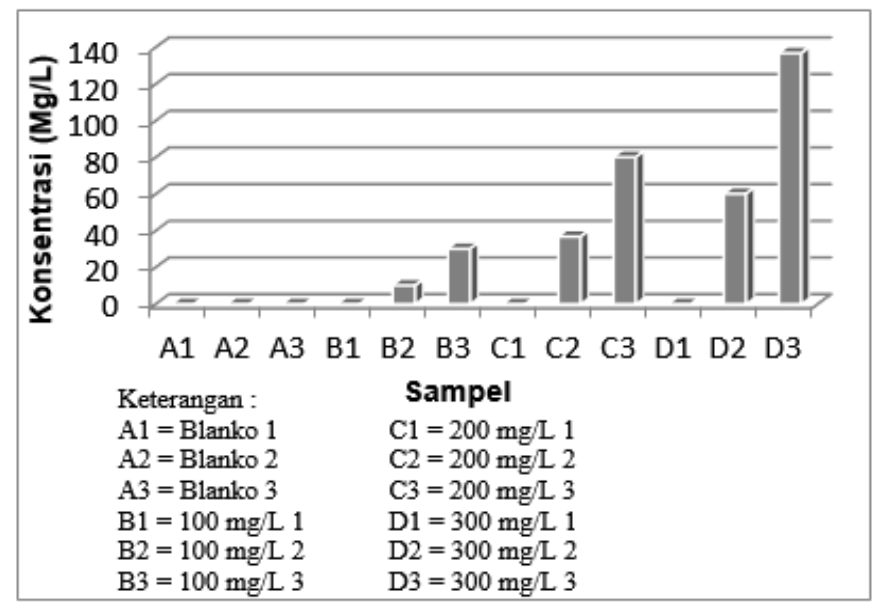

Gambar 3. Removal limbah artifisial logam Zn hari ke -15 .

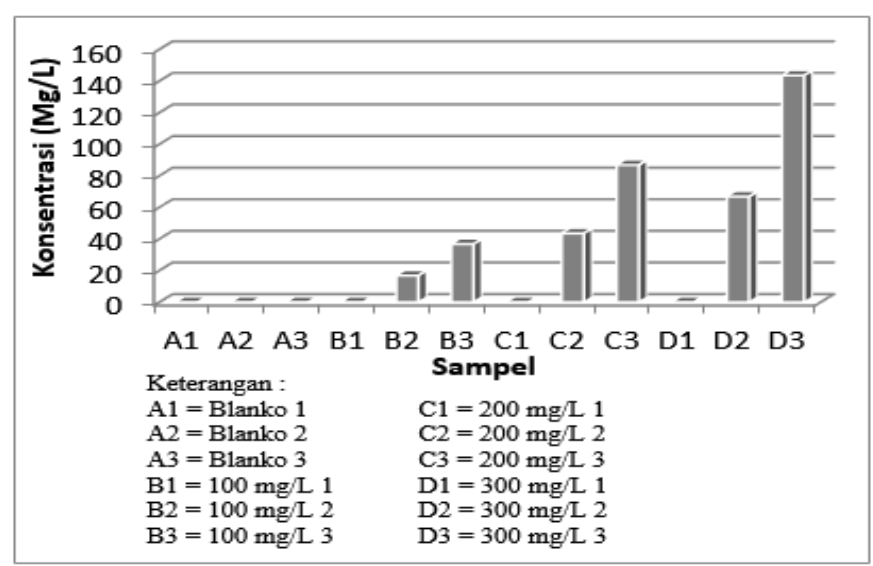

Gambar 4. Removal limbah artifisial logam Zn hari ke - 20.

penelitian ini diperlukan 9 bak perlakuan dan 3 bak kontrol dengan jumlah tanaman sebanyak 12 Avicennia marina. Penelitian ini menggunakan reaktor berupa ember dengan ukuran $270 \mathrm{~mm}$ x $233 \mathrm{~mm}$. Reaktor diisi dengan media tanah dengan ketinggian media $5-10 \mathrm{~cm}$ dan volume air sebaanyak $8 \mathrm{~L}$.

Pelaksanaan penelitian diawali dengan penelitian pendahuluan dengan mempersiapkan media dan tanaman. Penelitian pendahuluan yang dilakukan meliputi aklimatisasi dan uji Range Finding Test. Aklimatisasi tanaman dilakukan supaya tanaman Avicennia marina dapat menyesuaikan diri dengan kondisi dan media yang akan digunakan pada tahap uji Range Finding Test dan uji paparan logam $\mathrm{Zn}$. Tahap ini dilakukan selama 7 hari menggunakan media tanah tanpa pencemar, dan menggunakan air PDAM. Sedangkan uji Range Finding Test dilakukan untuk mengetahui seberapa besar kemampuan tanaman dalam menyerap polutan pada konsentrasi tertentu selama 7 hari. Variasi konsentrasi yang digunakan yaitu $0 \%$ (kontrol), $100 \mathrm{mg} / \mathrm{L}, 200 \mathrm{mg} / \mathrm{L}, 300 \mathrm{mg} / \mathrm{L}, 400 \mathrm{mg} / \mathrm{L}$, dan $500 \mathrm{mg} / \mathrm{L}$. Pada penelitian utama yaitu tahap uji logam $\mathrm{Zn}$ dengan jenis tanaman Avicennia marina. Pada tahap ini yang harus dilakukan yaitu mempersiapkan limbah sampel artifisial $\mathrm{ZnSO} 4.7 \mathrm{H} 2 \mathrm{O}$ dengan konsentrasi berdasarkan hasil uji Range Finding Test pada penelitian pendahuluan. Parameter yang diukur yaitu logam $\mathrm{Zn}, \mathrm{pH}$ dan suhu. 


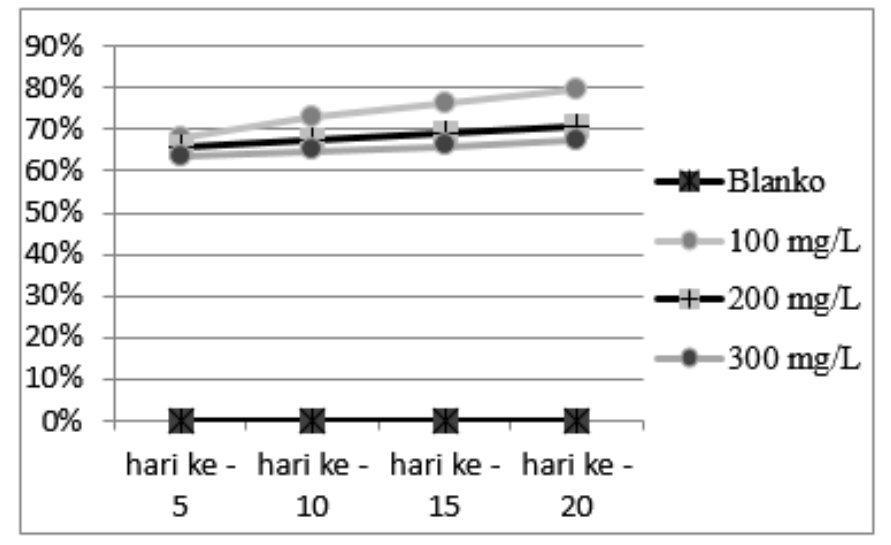

Gambar 5. Rata - rata efisiensi removal Avicennia marina.

\section{HASIL DAN PEMBAHASAN}

\section{A. Tahap Aklimatisasi}

Tahap aklimatisasi merupakan sebuah tahapan dalam upaya penyesuaian adaptasi dari suatu organisme terhadap suatu lingkungan baru yang akan dimasukinya. Pada hal ini aklimatisasi tanaman dilakukan supaya tanaman Avicennia marina dapat menyesuaikan diri dengan kondisi dan media yang akan digunakan pada tahap uji Range Finding Test dan uji paparan logam $\mathrm{Zn}$.

Proses aklimatisasi dilakukan dengan cara meletakkan tanaman pada reaktor yang akan digunakan pada penelitian uji paparan logam $\mathrm{Zn}$. Tahapan ini dilakukan selama 7 hari dengan menggunakan media tanah tanpa pencemar dan menggunakan air PDAM. Pada proses aklimatisasi tersebut, tanaman Avicennia marina dapat hidup dengan baik dalam keadaan tidak mati dan tidak layu. Tanaman ini yang akan digunakan pada uji Range Finding Test dan uji paparan logam $\mathrm{Zn}$.

\section{B. Uji Range Finding Test}

Range Finding Test (RFT) dilakukan untuk mengetahui seberapa besar kemampuan tanaman Avicennia marina dalam menyerap polutan logam $\mathrm{Zn}$ pada konsentrasi tertentu. Tahapan ini dilakukan dengan membuat variasi konsentrasi polutan logam Zn yang kemudian akan diujikan pada tanaman pengolah. Tanaman yang digunakan dalam Range Finding Test ini adalah tanaman hasil aklimatisasi sebelumnya. Variasi konsentrasi logam $\mathrm{Zn}$ yang digunakan dalam tahap Range Finding Test ini adalah 0 ppm (kontrol), 100 ppm, 200 ppm, 300 ppm, 400 ppm, dan 500 ppm.

Pada uji Range Finding Test digunakan reaktor berupa ember dengan ukuran $270 \mathrm{~mm}$ x $233 \mathrm{~mm}$. Volume air limbah yang digunakan sebanyak $8 \mathrm{~L}$, dengan media tanah dengan ukuran tingginya $9 \mathrm{~cm}$. Tahapan ini dilakukan selama 7 hari. Melalui tahap Range Finding Test ini juga akan diketahui konsentrasi yang tidak memberikan efek kematian pada tanaman seperti daun menguning, terdapat bercak - bercak cokelat dan terdapat banyak lubang pada daun. Konsentrasi yang tidak memberikan efek kematian ini yang nantinya akan digunakan pada uji penelitian utama yaitu paparan logam $\mathrm{Zn}$.

Dari hasil pengamatan selama 7 hari, dapat dilihat bahwa tanaman Avicennia marina mampu hidup dengan baik dengan konsentrasi 100 ppm, 200 ppm dan juga 300 ppm ditandai dengan daun yang tidak layu dan tidak menguning, Sedangkan pada konsentrasi 400 ppm dan 500 ppm, tanaman Avicennia marina mengalami kematian, daun menguning, dan terdapat lubang pada daun maupun bercak - bercak coklat.

\section{Analisa Logam Zn}

Analisa logam $\mathrm{Zn}$ dilakukan untuk mengetahui kemampuan tanaman mangrove Avicennia marina ketika di paparkan limbah artifisial logam Zn. Sampel limbah diambil selama 5 hari sekali dalam waktu 20 hari. Lama pengamatan ini untuk mengetahui kemampuan optimum tanaman mangrove Avicennia marina dalam menyerap pencemar logam $\mathrm{Zn}$. Limbah artifisial logam $\mathrm{Zn}$ yang digunakan terdiri dari berbagai konsentrasi dimulai dari blanko, $100 \mathrm{mg} / \mathrm{L}, 200 \mathrm{mg} / \mathrm{L}$ dan $300 \mathrm{mg} / \mathrm{L}$ sesuai dengan hasil uji Range Finding Test. Semua konsentrasi dilakukan sebanyak triplo atau tiga kali pengulangan. Pada setiap pengulangan dilakukan perlakuan yang berbeda, pengulangan yang pertama dengan menggunakan $100 \%$ air yang sesuai dengan pertumbuhan mangrove, pengulangan kedua $75 \%$ air yang sesuai dengan pertumbuhan mangrove $+25 \%$ konsentrasi air limbah artifisial logam $\mathrm{Zn}$, pengulangan ketiga $50 \%$ air yang sesuai dengan pertumbuhan mangrove $+50 \%$ air limbah artifisial logam $\mathrm{Zn}$.

Tanaman mangrove memiliki kemampuan menyerap logam tetapi dalam jumlah yang bervariasi dan tergantung dari jenis mangrovenya. Penyerapan logam berat ditentukan oleh tipe jaringan dan perlakuan yang diberikan [10]. Sehingga yang paling menentukan adalah jenis/spesies tanaman dimana hal ini digunakan tanaman Avicennia marina. Sejumlah tanaman terbukti memiliki sifat hiperakumulasi, yakni mampu mengakumulasi unsur logam tertentu dengan konsentrasi tinggi pada jaringan akar dan tajuknya, sehingga bersifat hiperakumulator [11]. Sifat hiperakumulator dapat digunakan untuk logam berat diserap oleh akar tanaman untuk disimpan, diolah atau dibuang saat dipanen. Tanaman mampu menyerap logam berat dan mentranslokasikannya ke bagian tanaman mulai dari akar hingga ke daun [12]. Berikut merupakan hasil kandungan paparan limbah artifisial logam $\mathrm{Zn}$ terhadap tanaman Avicennia marina selama 5 hari, 10 hari, 15 hari dan 20 hari dalam Gambar 1,2,3 dan 4.

Hasil pengamatan Gambar 1-4 menunjukkan bahwasanya pada pengulangan pertama konsentrasi $100 \mathrm{mg} / \mathrm{L}, 200 \mathrm{mg} / \mathrm{L}$ maupun $300 \mathrm{mg} / \mathrm{L}$ menghasilkan $0 \mathrm{mg} / \mathrm{L}$ limbah logam $\mathrm{Zn}$ karena hanya diisi dengan air yang sesuai dengan pertumbuhan mangrove yang tidak terdapat limbah Zn. Sedangkan pada pengulangan kedua dan ketiga konsentrasi $100 \mathrm{mg} / \mathrm{L}, 200 \mathrm{mg} / \mathrm{L}$ dan $300 \mathrm{mg} / \mathrm{L}$ terdapat pengurangan yang signifikan dari masing - masing konsentrasi terutama pada pemaparan hari ke -5 . Pada gambar di atas dapat dilihat bahwasanya semakin banyak penambahan air yang sesuai pada pertumbuhan mangrove maka pengurangan limbah artifisial logam $\mathrm{Zn}$ juga semakin banyak. Kemampuan menyerap limbah artifisial logam $\mathrm{Zn}$ pada tanaman mangrove Avicennia marina semakin hari semakin menurun yang dapat dilihat pada Gambar 1-4.

Setelah mengetahui kemampuan menyerap mangrove dalam bentuk konsentrasi, didapatkan rata - rata efisiensi removal masing - masing mangrove pada hari ke -5 , ke 10, ke -15, dan ke -20 dalam bentuk presentase seperti Gambar 5 . 
Pada gambar diatas dapat dijelaskan bahwa efisiensi removal pada konsentrasi $100 \mathrm{mg} / \mathrm{L}$ dari hari ke - 5 hingga hari ke - 20 yaitu $68,17 \%, 73,17 \%, 76,50 \%$ dan $79,83 \%$. Sedangkan pada konsentrasi $200 \mathrm{mg} / \mathrm{L}$ efisiensi removal yang didapat berturut - turut yaitu $65,75 \%, 67,42 \%, 69,08 \%$ dan $70,75 \%$. Pada konsentrasi $300 \mathrm{mg} / \mathrm{L}$ didapatkan efisiensi removal berturut - turut yaitu $63,83 \%, 64,94 \%, 66,06 \%$ dan $67,17 \%$. Efisiensi removal terbesar terdapat pada konsentrasi $100 \mathrm{mg} / \mathrm{L}$ pada hari ke - 20 sedangkan konsentrasi $200 \mathrm{mg} / \mathrm{L}$ dan $300 \mathrm{mg} / \mathrm{L}$ tidak lebih besar kemampuan efisiensi removalnya dari konsentrasi $100 \mathrm{mg} / \mathrm{L}$.

Tanaman yang mampu menyerap/mengakumulasi pencemar dalam tubuhnya disebutnya tanaman akumulator. Apabila kemampuan menyerapnya sebanyak 100 ppm dianggap tanaman hiperakumulator [13]. Sehingga tanaman mangrove Avicennia marina merupakan tanaman yang potensial sebagai hiperakumulator. Seperti halnya tanaman akuatik lain yang digunakan dalam fitoremediasi [14].

Proses penyerapan logam berat Zn yang dilakukan oleh akar disebut rhizofiltrasi. Tanaman mengeluarkan senyawa organik dan enzim melalui akar yang disebut eksudat akar sehingga daerah rhizosfer merupakan lingkungan yang sangat baik untuk tempat tumbuhnya mikroba dalam tanah. Mikroba tersebut akan mempercepat proses rhizofiltrasi. Logam dalam bentuk ion-ion logam dapat larut dalam lemak dam mampu melakukan penetrasi pada membran sel, sehingga ion logam akan terakumulasi di dalam sel dan jaringan. Logam dapat masuk dalam sel dan berikatan dengan enzim sebagai katalisator, sehingga reaksi kimia di sel akan terganggu. Gangguan dapat terjadi pada jaringan epidermis, sponsa dan palisade. Kerusakan tersebut dapat ditandai dengan nekrosis dan klorosis pada tanaman [15].

Sebagai upaya untuk mencegah keracunan logam terhadap sel dan jaringan, tanaman mangrove mempunyai mekanisme detoksifikasi, misalnya dengan menimbun logam di dalam organ tertentu seperti akar [16]. Adanya akumulasi logam merupakan usaha lokalisasi yang dilakukan oleh tanaman mangrove dengan mengumpulkan dalam satu organ [17]. Dalam sel tanaman logam melewato plasmalema, sitoplasma, dan vakuola, dimana logam akan dilokalisasi/terakumulasi dalam vakuola.

Tanaman mangrove memiliki pengaruh dalam penanggulangan materi toksik lain di antaranya dengan melemahkan efek racun melalui pengenceran (dilusi), yaitu dengan menyimpan banyak air untuk mengencerkan konsentrasi logam berat dalam jaringan tubuhnya sehingga mengurangi toksisitas logam tersebut [18]. Hal ini pun berbanding lurus dengan hasil penelitian yang di dapat bahwasanya kedua tanaman mangrove dapat menyerap logam secara signifikan pada hari ke -5 dan ini di akibatkan oleh presentase pengenceran pada penambahan nutrien air pada kedua tanaman mangrove dimana semakin besar presentase nutrien airnya, maka penyerapan logam melalui dilusi pun jadi semakin besar.

Mangrove adalah salah satu tanaman yang mampu beradaptasi dengan baik dalam lingkungan air, bahkan air payau maupun asin. Kemampuan berbagai spesies mangrove beradaptasi dengan lingkungan basah berbeda-beda. Spesies yang mendominasi adalah Avicennia sp., Soneratia griffithii dan Rhizopora, semua spesies dapat hidup tetapi yang mendominasi adalah Rhizopora. Tanaman yang tumbuh di air akan terganggu oleh bahan kimia toksik dalam limbah. Pengaruh polutan terhadap tanaman mangrove dapat berbeda tergantung pada macam polutan, konsentrasinya dan lamanya polutan itu berada [19]. Sistem perakaran tanaman mangrove yang besar dan luas dapat menahan dan memantapkan sedimen tanah, sehingga mencegah tersebarnya bahan tercemar ke area yang lebih luas dan memungkinkan tersebarnya bahan pencemar secara fisik.

Hal diatas berbanding lurus dengan hasil penelitian paparan logam $\mathrm{Zn}$ yang didapat bahwasanya konsentrasi dan lamanya pemaparan juga mempengaruhi efisiensi removal logam $\mathrm{Zn}$, bahwasanya semakin tinggi konsentrasi maka kemampuan mangrove tersebut semakin menurun. Dan semakin lama waktu pemaparan maka kemampuan mangrove tersebut terhadap paparan logam Zn semakin berkurang. Mangrove ini digunakan selama 20 hari yang di paparkan limbah artifisal logam $\mathrm{Zn}$ dimulai dari hari pertama hingga hari ke 20 dengan kondisi dan perlakuan yang sama.

\section{Analisa suhu}

Analisa suhu dilakukan pada reaktor yang memasuki masa penelitian utama setelah Range Finding Test yang dilakukan selama 20 hari dan diambil selama 5 hari sekali. Pengukuran suhu dilakukan dengan menggunakan alat termometer. Suhu merupakan derajat atau tingkat panas. Pengukuran suhu bertujuan untuk mengetahui suhu dari limbah artifisial logam $\mathrm{Zn}$ pada setiap reaktor. Suhu mempunyai pengaruh yang besar terhadap proses pertukaran zat (metabolisme) pada makhluk hidup [20].

Faktor lingkungan suhu semua reaktor berkisar $29^{\circ} \mathrm{C}-31^{\circ} \mathrm{C}$ selama 20 hari pada tanaman Avicennia marina. Pada hari ke 5 suhu tanaman yaitu $30^{\circ} \mathrm{C}$, hari ke -10 yaitu $29^{\circ} \mathrm{C}$ sedangkan pada hari ke -15 dan 20 suhu tanaman yaitu $30^{\circ} \mathrm{C}$. Reaktor diletakkan di dalam Halaman belakang Jurusan Teknik Lingkungan ITS di luar laboratorium sehingga mempengaruhi cahaya matahari yang mengakibatkan tingginya suhu setiap reaktor. Fluktuasi suhu ini dapat dipengaruhi oleh suhu lingkungan di lokasi. Suhu udara berpengaruh terhadap pertumbuhan tanaman karena adanya proses metabolisme tubuh tanaman. Pengukuran suhu dalam penelitian ini bertujuan untuk mengetahui perubahan suhu pada air limbah artifisial selama 20 hari. Kisaran suhu optimum untuk pertumbuhan mangrove yaitu kisaran $26-30{ }^{\circ} \mathrm{C}$ [21]. Hasil pengukuran suhu yang dilakukan pada tanaman Avicennia marina masih berada dalam rentang suhu tanaman yang pertumbuhannya dapat tumbuh dengan baik dan optimum.

\section{E. Analisa $\mathrm{pH}$}

Pengukuran $\mathrm{pH}$ dilakukan pada reaktor yang memasuki masa penelitian utama setelah Range Finding Test yang dilakukan selama 20 hari dan diambil selama 5 hari sekali. Pengukuran $\mathrm{pH}$ diukur dengan menggunakan $\mathrm{pH}$ meter di dalam laboratorium. Nilai $\mathrm{pH}$ menunjukkan konsentrasi ion $\mathrm{H}^{+}$dan ion $\mathrm{OH}$ pada limbah $\mathrm{Zn}$. Semakin tinggi ion $\mathrm{H}^{+}$menandakan bahwa limbah tersebut bersifat asam. Semakin tinggi ion $\mathrm{OH}^{-}$ menandakan bahwa limbah tersebut bersifat basa.

Hasil analisa $\mathrm{pH}$ menunjukkan bahwa $\mathrm{pH}$ pada air limbah artifisial $\mathrm{Zn}$ berfluktuasi pada kisaran 7,76-8,89 pada tanaman Avicennia marina. Dari hari ke 5 hingga ke 20 yang artinya 
semakin lama waktu pemaparan, $\mathrm{pH}$ di masing-masing reaktor dari mulai blanko hingga paparan limbah artifisial $\mathrm{Zn} 300$ $\mathrm{mg} / \mathrm{L}$ menuju ke arah yang semakin turun pHnya atau ke arah yang lebih rendah. Hal ini dikarenakan terjadi proses respirasi tanaman yang menghasilkan $\mathrm{CO}_{2}$ yang dapat menurunkan nilai $\mathrm{pH}$. Hal ini terjadi karena $\mathrm{CO}_{2}$ yang dikeluarkan tanaman dari hasil respirasi dimanfaatkan kembali untuk proses fotosintesis sehingga akan menggeser keseimbangan ke arah kanan yang berarti ada pengurangan ion $\mathrm{H}^{+}$(asam) pada limbah artifisial $\mathrm{Zn}$. Untuk $\mathrm{pH}$ optimum $\mathrm{Zn}^{2+}$ yang teradsorpsi terjadi pada pH 6 dan 7 [22]. Hal ini berbanding lurus dengan kondisi real yang terdapat pada limbah industri elektroplating bahwasanya $\mathrm{pH}$ dalam industri tersebut sebesar 6. Hasil analisis $\mathrm{pH}$ didapatkan dengan kisaran $\mathrm{pH}$ 7,85-8,99, walaupun tidak optimum tetapi tanaman Avicennia marina dapat tumbuh dengan baik dan menyerap limbah artifisial dengan baik dalam jangka waktu 20 hari.

\section{KESIMPULAN}

Berdasarkan penelitian yang telah dilakukan, maka dapat diambil kesimpulan bahwa efisiensi removal mangrove Avicennia marina terhadap limbah artifisial logam $\mathrm{Zn}$ pada konsentrasi $100 \mathrm{mg} / \mathrm{L}$ yaitu 79,83\%. Sedangkan pada konsentrasi $200 \mathrm{mg} / \mathrm{L}$ sebesar $70,75 \%$. Kemudian pada konsentrasi $300 \mathrm{mg} / \mathrm{L}$ sebesar 67,17\%.

\section{UCAPAN TERIMA KASIH}

Penulis mengucapkan terimakasih kepada Pengelola Ekowisata Mangrove Wonorejo Surabaya atas sumbangan tanaman mangrove Avicennia marina untuk keperluan penelitian, serta kepada dosen penguji tugas akhir yang telah memberi kritik dan saran terhadap penulisan jurnal ini.

\section{DAFTAR PUSTAKA}

[1] A. Said and M. A. K. Smith, "Proyek Rehabilitasi dan Pengelolaan Mangrove di Sulawesi: Ekonomi Sumberdaya. Laporan Akhir," Jakarta, 1997.

[2] P. . Tomlinson, The Botany of Mangroves. Cambridge University Press, 1986.

[3] G. R. Macfarlane, A. Pulkownik, and M. D. Burchett, "Accumulation and Distribution of Heavy Metals in the Grey Mangrove, Avicennia marina (Forsk) Vierh: Biological Indication
Potential," Environ. Pollut., vol. 123, no. 1, pp. 59-131, 2003.

[4] P. Arisandi, "Bioakumulasi logam berat dalam pohon bakau (Rhizophora mucronata B1.) dan pohon api-api (Avicennia marina (Forsk.) Vierh. Rob.)," 2008. .

[5] E. Istiyono, "Pengolahan Limbah Industri Penyepuhan Logam Perak (Elektroplating) di Lingkungan Pengrajin Perak Kecamatan Kotagede," J. FMIPA dan PGSD FIP Univ. Negeri Yogyakarta, vol. 12, no. 2, pp. $184-192,2008$.

[6] K. Sumada, "Kajian Instalasi Pengolahan Air Limbah Industri Elektroplating yang Efisien," J. Tek. Kim., vol. 1, no. 1, 2006.

[7] A. K. Meena, G. K. Mishra, and P. K. Rai, "Removal of Heavy Metal Ions from Aqueous Solution using Carbon Aerogel as an Adsorbent," J. Hazard. Mater., vol. 122, pp. 161 - 170, 2005.

[8] Y. Li, Q. Yue, and B. Gao, "Adsorption Kinetics and Desorption of $\mathrm{Cu}$ (II) and $\mathrm{Zn}$ (II) from Aqueos Solution onto Humic Acid," $J$. Hazard. Mater., vol. 178, pp. 455-461, 2010.

[9] A. Gerhardt, D. B. L. Janssens, and A. M. V. M. Soares, "Macroinvertebrate Response to Acid Mine Drainage; Community Metrics and On-line Behavioural Toxicity Bioassay," J. Environ. Pollut., vol. 130, no. 2, pp. 263-274, 2004.

[10] A. S. Knox, Chemostabilization of Metals in Contaminated Soils. New York: Marcek Dekker Inc, 2000.

[11] N. Hidayati, "Fitoremediasi dan Potensi Tanaman Hiperakumulator," Bogor, 2005.

[12] G. S. Panjaitan, A. Dalimunthe, and Yunasfi, "Akumulasi Logam Berat Tembaga $(\mathrm{Cu})$ dan Timbal $(\mathrm{Pb})$ Pada Pohon Avicennia marina di Hutan Mangrove," Medan, 2009.

[13] W. Widowati, Efek Toksik Logam Pencegahan dan Penanggulangan Pencemaran. Yogyakarta: Andi, 2008.

[14] B. V. Tangahu, "Comparison of Single Plant And Combined Plants Using Reedbed System In Treating Batik Industry Wastewater," in International Postgraduate Conference on Biotechnology, 2015.

[15] M. Haryati, "Kemampuan Tanaman Genjer (Limnocharis Flava (L.) Buch) Menyerap Logam Berat Timbal (Pb) Limbah Cair Kertas pada Biomassa dan Waktu Pemaparan yang Berbeda," Lateral Bio, vol. 1, no. 3, 2012.

[16] B. Priyanto and J. Prayitno, "Fitoremediasi sebagai Sebuah Teknologi Pemulihan Pencemaran Khusus Logam Berat," J. Inf. Fitoremediasi, 2004.

[17] N. M. Heriyanto and E. Subiandono, "Penyerapan Polutan Logam Berat $(\mathrm{Hg}, \mathrm{Pb}$ dan $\mathrm{Cu})$ oleh Jenis-Jenis Mangrove," 2011.

[18] H. Palar, Pencemaran dan Toksikologi Logam Berat. Jakarta: Rineka Cipta, 1994.

[19] A. J. M. Baker, "Terrestrial Higher Plants Which Hyper Accumulate Metallic Elements-A Review of Their Distribution, Ecology and Distribution," J. Biorecovery, vol. 1, pp. 81-126, 1989.

[20] D. Permana, "Keanekaragaman Makrobentos di Bendungan Bapang dan Bendungan Ngablabaan Sragen," Surakarta, 2003.

[21] P. Hutchings and P. Saenger, Ecology of Mangrove Aust, Eco. Series. St Lucia Quesland: University of Queensland Press, 1987.

[22] R. I. Pratama, M. Y. Awaluddin, and S. Ishmayana, "Analisis lebih komposisi,” J. Akuatika, vol. 2, no. 2, pp. 1-11, 2011. 